\title{
MulawarmanLawReview
}

\section{Normative Protection of Traditional Knowledge and Traditional Cultural Expressions in Indonesia}

\author{
Gabriel Theofani \\ Alumni of Magister's Program Faculty of Law, Mulawarman University \\ E-mail: gtheofani@gmail.com
}

\begin{abstract}
It is undeniable that the flow of globalization plays a major role in every aspect of state life, including the field of law and the legal product itself. Indonesia as a WTO member is obliged to ratify various types of international agreements to be made into domestic law products in the form of the Law. One of the important issues that must be protected is Intellectual Property Rights which is compiled based on the TRIPs standard. In its development, the concepts and characteristics of IPR have caused losses to developing countries such as Indonesia which have many assets in the form of traditional knowledge and traditional cultural expressions held by local communities. The IPR legal regime cannot accommodate the protection of traditional knowledge and traditional cultural expressions as a whole. The direction of legal regulation that protects traditional knowledge and traditional cultural expressions today is to form a new legal product that is specifically outside the IPR regime. The Bill on Traditional Knowledge and Traditional Cultural Expressions has long been composed by Indonesia since 2008 and included in the 2009-2014 National Legislation Program. But even until now there has been no approval made by the government. The normatification of this bill is very important to be done so that it can be given that traditional knowledge and traditional cultural expressions can be used as an aid for advancing the nation's economy. By using normative legal research methods and qualitative approaches, this study concludes that the IPR legal regime in Indonesia has not been able to provide maximum protection to traditional knowledge and traditional cultural expressions. Therefore, it is very important to discuss and ratify the Bill on Traditional Knowledge and Traditional Cultural Expressions to become products law to guarantee protection and provide economic benefits to the State and society.
\end{abstract}

Keywords: Normative; Protection traditional Knowledge; Traditional Cultural Expressions.

Citation: Theofani, Gabriel, "Normative protection of traditional Knowledge and Traditional Cultural Expressions in Indoneisa." Mulawarman Law Review 3, no. 1 (2018): 97-112

\section{INTRODUCTION}

Globalization is a matter that absolutely cannot be avoided by everyone. The process of globalization can bring a major impact for each country, its influence can rapidly get into important aspects such as economics, politics, socio-culture, science and technology, and so forth. 
Indonesian is one of the Countries that is affected from this globalization, with an open economic era demanding competition that cannot be avoided, one of which is the marketing of goods is no longer limited to one country but globalized. With the era of open competition, Indonesia is required to be able to maintain competition between foreign products and domestic products to ensure fair and fair competition based on international international agreements. To accommodate the open economic competition, one of the world organizations that secure it is the WTO (World Trade Organization). Indonesia, as one of the WTO members, is obliged to adjust various kinds of international agreements to be made into legal products in the country in the form of Law. One important issue that has come to WTO's concern is the legal protection of Intellectual Property Rights which is compiled based on TRIP's (Trade Related Aspects of Intellectual Property Rights) standards. Intellectual Property Rights themselves are rights to property that arise or are born due to human intellectual abilities in the form of knowledge, art, literature, technology, where in realizing it requires sacrifice of energy, time, cost, and mind. It is due to that sacrifice that a work has value. And if added to the economic benefits that can be relished, then the inherent economic value fosters a conception of property towards the intellectual work. $^{1}$

In its development, the concept of current IPR protection raises a variety of strategic issues that lead to the interests of developing countries, including Indonesia. ${ }^{2}$ The concept of IPR protection that prioritizes aspects of authenticity and individualism is deemed unsuitable if applied to developing countries such as Indonesia that have potential in the field of traditional knowledge and traditional cultural expressions (Folklore) which are owned by traditional communities spread throughout Indonesia. Until now, there has not been a general meeting point on the scope and understanding of traditional knowledge and traditional cultural expressions. But in the article 8J Traditional Knowledge, Innovations, and Practice Introductions, it mentioned that "Traditional knowledge refers to knowledge, innovation, and practice of native and local communities throughout the world. Developed from experience through countries and adapted to local culture and the environment, traditional knowledge is transmitted orally from generation to generation. It becomes a collective ownership and takes the form of stories, songs, folklore, proverbs, cultural values, beliefs, rituals, community law, regional languages and agricultural practices, which involves the development of plant species and descendants of animals. Traditional knowledge is primarily a natural practice, specifically as in the areas of agriculture, fisheries, health, horticultural, and forestry.

The difference in the concept of ownership between Intellectual Property Rights and Traditional Knowledge and the Traditional Cultural Expressions raises a problem in enforcing its legal protection. The characteristics of IPR that prioritize aspects of authenticity and individualism are in sharp contrast to the nature of Traditional Knowledge and Traditional Cultural Expressions that are collective and passed down from generation to generation. The cultural wealth in the form of Traditional

${ }^{1}$ Bambang Kesowo dalam Budi Agus Ruswandi, Hak Kekayaan Intelektual dan Budaya Hukum, Raja Grafindo Perkasa, 2004.

2 Yasmi Adriansyah, Mencari Tempat Terhormat Indonesia, PT. Alumni, Bandung, 2010, hlm 95. 
Knowledge and Traditional Cultural Expression also holds enormous economic potential so that it can support the process of sustainable economic development. It is not surprising that this value has caused foreign parties to repeatedly use it without permission and / or recognize Traditional Knowledge and Traditional Cultural Expressions in Indonesia as their own. In the long term, these actions can be detrimental to national interests, because as the time passes by, more and more Traditional Knowledge (PT) and Traditional Cultural Expressions (EBT) of Indonesia will be taken over by other nations, while in terms of national interests in Indonesia alone cannot calculate the amount of potential for sustainable economic benefits can be obtained from the intellectual property of the nation's cultural heritage. ${ }^{3}$

One issue that has happened in Indonesia is the case of claims of Indonesia's traditional knowledge and traditional cultural expressions by Malaysia. In an advertisement on the Discovery Channel in Enigmatic Malaysia, Pendet, Wayang, and Reog Ponorogo dances are claimed to be Malaysian traditional wealth. In spite of the fact all three of them are actually Indonesia's traditional cultural expressions. ${ }^{4}$ This proves that actual measures is needed to be taken by the State, both the community and especially the government to be able to determine their stances and immediately make policies that can protect the nation's inheritance in the form of Indonesia's traditional knowledge and traditional cultural expressions. The types of intellectual property in international trade which legal protection arrangements are regulated in the Agreement on Trade Related Aspects of Intellectual Property Rights (TRIPs), include: ${ }^{5}$ (1) Copyrights, (2) Trademarks, (3) Geographical indication, (4) Industrial designs, (5) Patent, (6) Integrated circuit lay-out designs,(7) Trade secret, (Article 1 paragraph (2) Trade Related Aspects of Intellectual Property Rights Including Trade in Counterfeit Goods / TRIPs). The division of the seven types of IPR above has negative implications for the types of rights that can be categorized as IPR outside of the seven types such as, traditional knowledge and traditional cultural expression not protected under the TRIPs framework. At present, to increase the legal awareness of the community in an effort to protect natural resources, especially culture and biodiversity contained in the Indonesian earth is often sought. Of course the intention is to oppose the many arguments that have been contested that have been put forward by foreign companies or foreigners in taking the wealth of Indonesian cultural arts, namely that abundant traditional resources and works which are an ancestral heritage that can be used by anyone and at anytime. Currently, the limitations of data, documentation, information, publications on the intellectual property of the nation, namely traditional knowledge, including folklore, as a nation's assets that have actually existed since hundreds of years ago, need to be dealt more seriously. In addition to these complicated matters, the protection of folklore through copyright is certainly very

\footnotetext{
${ }^{3}$ Naskah Akademik Pengetahuan Tradisional, 2006, Jakarta, BPHN dan Ditjen HKI RI, hlm 2

4 Badan Penelitian dan Pengembangan HAM Kementerian Hukum dan HAM RI, Perlindungan Kekayaan Intelektual Atas Pengetahuan Tradsional dan Ekspresi Budaya Tradisional Masyarakat Adat, Penerbit PT. Alumni, Bandung, 2013, hlm.3.

${ }^{5}$ Badan Penelitian dan Pengembangan HAM Kementrian Hukum dan HAM RI, hlm 1
} 
difficult because it must be characterized by its originality and individuality (the creator is known). ${ }^{6}$

At the national level, there is no adequate rules of legislation regarding traditional knowledge and traditional cultural expressions as reflected in Article 38 of Act Number 28 of 2014 concerning Copyright which only states that:

1. The copyright on traditional cultural expressions is owned by the State.

2. The State must record, maintain and preserve traditional cultural expressions as referred to in paragraph (1).

3. The use of traditional cultural expressions as referred to in paragraph (1) must pay attention to the values that live in the owning community.

4. Further provisions regarding Copyright which held by the State for traditional cultural expressions as referred to in paragraph (1) shall be regulated by Government Regulation.

The absence of a proper legal protection for legal certainty (up until now still in the form of the Traditional Knowledge Bill) regarding traditional knowledge including folklore, could possibly obstruct the law enforcement. In addition to regulations that have not explicitly regulated the protection of Traditional Knowledge and Traditional Cultural Expressions, there are other factors that caused the protection of Traditional Knowledge and Traditional Cultural Expressions to have not received maximal protection, in this case there are 3 fundamental issues related to the protection of Traditional Knowledge and Traditional Cultural Expressions, namely?

1. Substantial aspects, have not been strictly regulated, whether substantially and procedurally to obtain legal protection, even if it exist, it is only symbolic so the rules are not effective and have no benefits.

2. Aspects of legal apparatus, there are still very few officials who know the problems of traditional knowledge and traditional cultural expressions, even though in terms of the unclear normative rules, legal breakthroughs, that may be carried out by the law enforcement officials, are very much needed.

3. Aspects of legal culture, lack of public legal awareness and reluctance of traditional communities to carry out legal processes in the context of violations of intellectual work based on traditional knowledge and traditional cultural expressions, on the other hand the government is expected to have legal ability and awareness to fight for the protection of traditional knowledge and traditional cultural expressions is still plagued by various problems.

The current direction of managing folklore and traditional knowledge leads to a separate form of IPR protection system, which in a sui generis manner will attempt to maintain traditional knowledge through preservation, protection, and promotion (utilization). The path is taken according to $\operatorname{Twarog}^{8}$ so that the approach to managing

\footnotetext{
${ }^{6}$ Endang Purwaningsih, Perlindungan Hukum Terhadap Kekayaan Intelektual Warisan Bangsa Sebagai Implikasi Yuridis Nilai-Nilai Kebangsaan Menuju Ketahanan Nasional, Jurnal NEGARAWAN Kementerian Sekretariat Negara RI Vol. 26, (Desember, 2012), hlm 2

7 Budi Agus Ruswandi, Hak Kekayaan Intelektual dan Budaya Hukum, Raja Grafindo Perkasa, 2004.

8 Sophia Twarog, 2006 dalam naskah Akademik Pengetahuan Tradisional, Jakarta, BPHN dan Ditjen HKI RI, hlm 39
} 
traditional knowledge can be carried out thoroughly (holistic approach), directed and integrated as well as able to concretize traditional knowledge as an asset in economic development.

Based on the discussion above, it is explained that there is still a lack of protection against Traditional Knowledge and Traditional Cultural Expressions and systematic steps are needed to be able to provide maximum protection. Based on the explanation above, the problem that is going to be investigated in this study can be formulated as, Is Traditional Knowledge and Traditional Cultural Expressions incorporated into the object scope of Intellectual Property Rights and how can the normatification of protection be carried out in an effort to provide legal protection against traditional knowledge? Based on the problems of the study, this study aims to analyze whether traditional knowledge and traditional cultural knowledge are incorporated into the object scope that is protected in the intellectual property rights legal regime or not as well as how can appropriate legal arrangements be given by the State to traditional knowledge and traditional cultural expressions in order to provide legal protection and certainty to the right-holders of traditional knowledge and traditional cultural expressions.

\section{METHOD}

This research uses normative approach that is written law research from various aspects such as aspect of the theory, history, philosophy, comparison, structure and composition, scope and material. Consistency, general explanation and article by article, formality and law's strength binding a legal rule along with legal language used.

This research done through library research. The first step in performing this research is to collecting data as in secondary data by reading literary works in the form of books containing theories about intellectual property rights, traditional knowledge, and traditional cultural expressions with study documents which will analyze legislation laws related to intellectual property rights along with other supporting documents such as international agreements, scientific journals and seminar papers.

Furthermore, these data will be analyzed quantitatively, comprehensively and thoroughly. the Quantitative specifically outlines data in a manner of regular sentence, organized, logical, does not overlapping and effective, so that it can simplify data interpretation and understanding the results of the analysis. Comprehensively which means an in-depth data analysis covering various aspects accordant with the scope of the study. Thoroughly means that the study will not forgotten any of the important parts, all of it will be included in the analysis. 


\section{DISCUSSIONS}

Traditional Knowledge and Traditional Cultural Expressions in the Legal system of Intellectual Property Rights

Definition (understanding) and the scope of Traditional Knowledge as an Intellectual Property

The term, Traditional knowledge is a general definition which includes creative expression, information and know how in particular such as it has its own characteristics that can identify social unit. In many ways, Knowledge meant here refer to the traditional environment knowledge. Discussion about traditional knowledge began to develop from year to year together with the renewals of law and policy, such as agricultural development policy, biodiversity (biological diversity) and Intellectual property. ${ }^{9}$

The definition of Traditional Knowledge contained in article $8 \mathrm{j}$ about Traditional Knowledge, Innovations and Practices Introduction that states: ${ }^{10}$

"Traditional knowledge refers to knowledge, innovation and practices of indigenous and local communities around the world. Devolved from experience gained over the centuries and adapted to the local culture and environment, traditional knowledge is transmitted orally from generation to generation. It tends to be collectively owned and takes the form of stories, songs, folklore, proverbs, cultural values, beliefs, rituals, community laws, local language and agricultural practices, including the development of plant species and animal breeds. Traditional knowledge is mainly of a practical nature, particularly in such fields as agriculture, fisheries, health, horticulture and forestry".

From the article above we understand that traditional knowledge can be interpreted as the knowledge, innovation, practice that are possessed by the local communities throughout the world. Developed from experience through countries and adapted to local tradition and environment, traditional knowledge is passed verbally from generation to generation. It became a collective property and took the form of stories, songs, folklores, proverbs, cultural values, beliefs, rituals, community law, local language and agricultural practice, involving the development of plant species and animals' descent. The primary traditional knowledge is scientific practice, specifically in the fields of agriculture, fishery, health, horticulture, and forestry. From the article above we understand that traditional knowledge can be interpreted as the knowledge,

\footnotetext{
9 Sebelum istilah "Hak Kekayaan Intelektual (HKI)" resmi dipergunakan, lebih umum dikenal dengan istilah "Hak atas Kekayaan Intelektual (HaKI)". Namun istilah HaKI sudah tidak dipakai lagi karena berdasarkan Keputusan Menteri Hukum dan Perundang-Undangan RI No. M.03.PR.07.10. Tahun 2000, telah ditetapkan secara resmi penggunaan istilah "Hak Kekayaan Intelektual (tanpa menggunakan kata "atas"). Adapun alasan perubahan istilah tersebut antara lain untuk lebih menyesuaikan dengan kaidah bahasa Indonesia yang tidak menulis kata depan seperti "atas" atau "dari", terutama untuk istilah. Lebih lanjut bisa dilihat dalam Ahmad Zen Umar Purba, "Pokok-Pokok Kebijakan Pembangunan Sistem HKI Nasional", Jurnal Hukum Bisnis, Vol.13, April 2001, Hlm.8, sebagaimana dikutip dalam Afrillyanna Purba, dkk, “TRIP's-WTO dan Hukum HKI Indonesia (Kajian Perlindungan Hak Cipta Seni Batik Tradisional Indonesia", Penerbit: Rineka Cipta, Jakarta, 2005, Hlm.26.

${ }^{10}$ Ibid, Hal. 27
} 
innovation, practice that are possessed by the local communities or a tradition that are passed from generation to generation. Meanwhile the scope of traditional knowledge is very broad, can covers field of arts, agriculture, architecture and others.

The problems constituted with traditional knowledge consist of important aspects that are very important to fight for and protected by the legal law because theoretically the traditional knowledge of a country is worth preserving for. There are two mechanics that could help in the effort to provide legal protection for traditional knowledge, such as protection in form of Intellectual Property Rights (IPR), regulations that manage genetic source of a traditional knowledge, contracts, customary law and nonregulatory effort comprise of code of conduct adopted by means of compiling research and findings, registering database of the traditional knowledge via an international effort, involvement of government and or non-government organizations, effort from professional community and or private sector.

Regulation that related with the preservation of traditional and traditional cultural expression in Indonesia

In the Act number 28 of 2014 it has been arranged in the article regarding traditional cultural expression and the intellectual right of it if the creator the traditional cultural expression is unknown. Regulated in article 38, Act number 28 of 2014 concerning intellectual rights:

a. Hak Cipta atas ekspresi budaya tradisional dipegang oleh Negara,

b. Negara wajib menginventarisasi, menjaga dan memelihara ekspresi budaya tradisional sebagaimana dimaksud pada ayat (1),

c. Penggunaan ekspresi budaya tradisional sebagaimana dimaksud pada ayat (1) harus memperhatikan nilai-nilai yang hidup dalam masyarakat pengembannya,

d. (4) Ketentuan lebih lanjut mengenai hak cipta yang dipegang oleh Negara atas ekspresi budaya tradisional sebagaimana dimaksud pada ayat (1) diatur dengan Peraturan Pemerintah.

e. The rights for traditional cultural expression is held by the State,

f. The State is required to record, preserves and maintain traditional cultural expression as is mentioned in paragraph (1),

g. The value of life of the traditional cultural expression as mentioned in paragraph (1) by the local community must be respected and appreciated

h. Further provisions on the intellectual rights of the traditional cultural expression held by the government mentioned in paragraph (1) regulated under government's law

Likewise explained in article 38 paragraph (1) also been given restriction on what is considered as "traditional cultural expression" that's is everything encompass one or more form of expressions as follows:

a. Verbal, textual, both oral and written, if form of proses and poetry, in various themes and content of the messages, could be in form of literary works or narrative informative;

b. Music, consists of vocal, instruments or combinations of both;

c. Motions, includes; dances 
d. Arts, consists of two dimensional arts, three dimensional arts made of woods, skins, bamboo, metal, stones, ceramic, paper, textile, etc.

e. Traditional ceremony.

In conclusion, although the definition or traditional cultural expression already included in article 38 paragraph (1) Law number 28 of 2014 concerning intellectual rights. However, the application of the regulation is not easy to be done. There are three reasons that caused it.

First, the formula or the definition contain unclear and lack of specific suitable terms. Second none of the rules in the regulation differentiates specifically which one is a traditional cultural expression and which ones are not. Third, there are no official institution with the authority in establishing traditional cultural expression as intellectual rights. Beside regulated in Law of intellectual rights, traditional knowledge of Indonesia also arranged in the Act number 29 of 2000 pertaining to the protection of varieties of plants. Including patent law. Aside from making use of the intellectual right regulation to protect traditional knowledge in Indonesia, the policy related to the traditional knowledge implicitly can be found such as in Act number 32 of 2009 regarding protection and management of living environment, specifically article 63 (1) (t) which states that in regards of protection and managing living environment, the government's duty and authority is to establish policies of the procedures in determining the existence of customary laws, local wisdom and the protection and managing environments for rights of the communities following customary laws. Looking at the statement of the article it is very clear that the government must obligated and necessarily recognize the existence and rights of the customary law's communities including traditional knowledge.

Aside from laws regulating intellectual rights, in Indonesia there is also other Laws that offers protection for traditional knowledge and traditional cultural expression, namely Act number 5 of 2017 concerning cultural advancement. The efforts to protect traditional knowledge and traditional cultural expressions based on the regulations is by creating a database of cultural information or wealth, then broadcasting them through the media so that everyone knows the culture originated from Indonesia. In broader terms, the Act number 5 of 2017 concerning the Advancement of Culture is an effort to increase cultural resilience and the contribution of Indonesian culture in the midst of world civilization through the protection, development, utilization, and fostering of cultures.

The differences in the Concept of Ownership Between Traditional Knowledge and Traditional Cultural Expressions with Intellectual Property Rights.

A wide understanding can be said that an Intellectual Property Rights are the right of the intellectual property that includes: knowledge, art, literature, and technology, where in realizing it requires sacrifice of energy, time, cost, and mind. The existence of these sacrifices creates an economic value for the intellectual work. ${ }^{11}$ The concept of ownership of intellectual work individually is applied to developing countries such as

11 Budi Agus Riswandi, M.Syamsudin, 2004 "Hak Kekayaan Intelektual dan Budaya Hukum", Jakarta. Raja Grafindo Persada,Hal. 31 
Indonesia consists of indigenous groups that are internationally known as local communities. As a result, there are obstacles in protecting their traditional knowledge, because indigenous people are not able to accept the individual concepts in the Intellectual Property Rights Law system. In the lives of the indigenous / local people who produce intellectual work to use it for the benefit of community, which is an effort to maintain a harmonious and conformable life among members of the community who produce the work, so as to prevent the occurrence of ownership conflicts. the indigenous peoples do not use individual concepts but emphasizes more on a communal life. This thinking in indigenous peoples is based on the assumption that each individual is an integral part of their society as a whole. It is also believed that each individual's interests must appropriately adjusted to the interests of the community, therefore no individual is detached from their community. ${ }^{12}$

This Traditional knowledge of the indigenous peoples / local which has been produced for years in a communal concept, is impossible to be accepted by the western system, because in the western legal system it is not possible to protect the rights of indigenous people or ethnic groups on their intellectual property which are generally not individually owned by the members of the community concerned. ${ }^{13}$

Based on the problems explained regarding the legal protection that been given by the Government to Traditional Knowledge and Traditional Cultural Expressions, at the level of the Intellectual Property Rights legal regime in Indonesia have not maximally provided a proper legal protection and provides certainty in protecting traditional knowledge and traditional cultural expressions of the Indonesian indigenous communities. This is reflected in the absence of specific regulations that further regulate traditional knowledge and traditional cultural expressions. Although there are several legal rules that have been promulgated but have not been able to accommodate overall protection for traditional knowledge and traditional cultural expressions.

\section{Normative Protection of Traditional Knowledge and Traditional Cultural Expressions} in Indonesia.

\section{Protection of Traditional Knowledge to support the Economic Development in Indonesia}

In the era of free trade, many countries have begun to look for alternative new products to trade by exploring traditional knowledge-based products from developing countries that have cultural wealth such as those in Indonesia to be acquired and further developed. So that the product is able to dominate the world market without any contribution to the country or society that owns the product. ${ }^{14}$ Issues in the field

\footnotetext{
12 Otje Salman Soemadiningrat. 2002. Rekonscptualisasi Hukum Adat Kontemporer, Bandung , Alumni. Hal. 31

${ }^{13}$ Agus Sardjono, 2004. "Pengetahuan Tradisional Studt Mengenai Perlindungan Hak Kekayaan Intelektual Atas Obat-Obatan" Jakarta : Badan Penerbit FHUI. Hal 134

14 Sudarmanto, Produk Kategori Indikasi Geografis Potensi Kekayaan Intelektual Masyarakat Indonesia, Lembaga Pengkajian Hukum Internasional Fakultas Hukum Universitas Indonesia, Jakarta, 2005, hlm. 109 -110 .
} 
of Intellectual Property Rights and indigenous rights have been a source of debate in recent years. The development to solve the issues surrounding this subject is not so easy given the complexity of the subject matter and the contradictions to recognize forms of IPR as a protection system that has been recognized internationally, and what is most appropriate IPR regimes to protect the rights of local communities in Indonesia.

Traditional knowledge related to Genetic Resources is a challenge for legislation in the IPR sector. The argument that tends to emerge is that individuals or companies have taken shared genetic resources for their own benefit and used these materials to develop products and earn income. Traditional knowledge related to Genetic Resources has a very high economic value in the world of commerce and can be regarded as a national asset. In order to analyze the system of protection of intellectual property rights are deemed to be in accordance with the expected / required by the indigenous / local (indigenous people), and in tune with the latest developments in the social, cultural, and economic. There are two (2) points that it is necessary to be carefully examined, namely: to ensure that traditional knowledge can be considered as prior art, and that the acquisition of intellectual property rights (e.g. patents) inappropriately can be prevented, ${ }^{15}$ and can further accelerate the realization of the expectations of the wider community, so that the use of genetic resources, traditional knowledge and expressions of folklore can be optimally carried out, as well as to make available their sui generis intellectual property system that is adequate in these areas. ${ }^{16}$ Some alternatives can be made by the government regarding the idea of protection that can be given to the rights of local people in Indonesia, such as forming new special legislation (sui generis) regarding the issue of access of foreigners to traditional Indonesian knowledge and the issue of sharing benefits to local community members for access and use of these resources. The action that also needs to be carried out by the Government of Indonesia is to stimulate the growth and development of community participation in order to participate in seeking to increase the use of traditional knowledge for the welfare of the community in a broad sense.

\section{Urgency of Legal Arrangements for Protection of Traditional Knowledge and Traditional Cultural Expressions.}

Lawrence M. Friedman argues that the law can work, must be fulfilled 3 (three) conditions: first, the rule must be communicated to the subject matter of its arrangement; second, the subject that is regulated has the ability to carry out the rule; third, the subject must have the motivation to implement the rule. ${ }^{17}$ Legal products (laws) regarding traditional knowledge must be able to be legally realized, so that in the future there is only a sociological implementation in society that reflects the

15 Asian - African Forum On Intellectual Property and Traditional Knowledge and Genetic Resources, 18-21 Juni 2007 di Bandung.

16 Ian F Spellerberg, Biological Diversity, Concerevation and Resource Management, Biodiversity Conservation in Asean Emerging Issues \& Regional Needs, Asean Academic Press, London, Printed and bound in Malaysia 2007, hlm. 7

17 Lawrence M. Friedman, The Legal System A Social Science Respective, Russel Sage Foundation, New York, 1975,hlm. 56. 
consequences of the application of these legal products. Regarding this matter, there are many interrelated factors in creating legal formation as stipulated in legal regulations in the form of laws. The government can consider the formulation of special legislation or sui generis which regulates the issue of foreign people's access to biological resources and knowledge of related traditional knowledge, as well as the distribution of benefits that occur due to such access. The same legislation can also include arrangements for contractual practices and clauses ${ }^{18}$ related to the provision of access and distribution of the benefits mentioned above.

Sistem Sui Generis diperlukan mengingat rezim HKI yang berlaku sekarang ini telah terbukti kurang sesuai untuk diterapkan dalam melindungi pengetahuan tradisional dari tindakan misappropriation oleh pihak asing. Perlindungan Paten, merek, desain dan sebagainya mungkin efektif untuk melindungi aspek ekonomis dari pengetahuan tradisional. Namun, tidak memadai untuk melindungi system pengetahuan tradisional yang bersifat holistik (mencakup aspek spiritual maupun cultural identity or integrity).

The Sui Generis system is needed considering that the current IPR regime has proven to be less suitable to be applied in protecting traditional knowledge from foreign misappropriation. Patent protection, brand, design and so on may be effective to protect the economic aspects of traditional knowledge. However, it is insufficient to protect traditional knowledge systems that are holistic in nature (including both spiritual aspects and cultural identity or integrity). The legal arrangement of Sui Generis which regulates the protection of Traditional Knowledge and Traditional Cultural Expressions has actually been proclaimed by the Government since 2008 and included in the National Legislation Program (Prolegnas 2010-2014). But until now The Bill on Traditional Knowledge and Traditional Cultural Expressions has not been validated as an Act that specifically protects the Traditional Knowledge and Traditional Cultural Expressions not only for intellectual property rights but also for nonintellectual property rights.

The bill of the Traditional Knowledge Law and the Traditional Cultural Expressions is very important to immediately be released so that it can implement the right protection system for Indonesian local communities. The most important substance that must be contained in this bill is the explicit recognition that the local community is the "owner" of the traditional knowledge concerned. Then the purpose of safeguards includes creating a system of preservation, protection and development of traditional knowledge, protecting the rights of traditional knowledge owners, developing the capacity of traditional knowledge-holding communities in Indonesia, enhancing national innovation based on traditional knowledge. The objects of protection of traditional knowledge and traditional cultural expressions are traditional knowledge including knowledge that is formed, preserved, and conveyed in traditional intergeneration contexts from generation to generation, has special characteristics related to certain communities that preserve and deliver between generations, integrated with certain people's cultures through habits which continues, the requirements or

18 Patricia Lucia Cantuaria Marin, Providing Protection for Plant Genetic Resources Patents, Sui Generis System, and Biopartnerships, Kluwer Law International, 2002, hlm. 77. 
criteria to get protection, the subject who becomes the bearer of his rights. The Intellectual Property Rights regime requires an individual creator or inventor. Whereas in the traditional knowledge system the creator or inventor cannot be identified individually.

In addition to determining the subject of the owners of traditional knowledge and traditional cultural expressions and objects of traditional knowledge and traditional cultural expression that should be protected, it should also have elaborated further about the rights that will be granted after the traditional owners and traditional cultural expressions are set either in the form of exclusive rights, the right moral and remuneration rights. Furthermore, how these rights are obtained by the rights holders, implementing and enforcing those rights, the loss of these rights or these rights expires, and how to resolve disputes that can be done if there is abuse in the utilization of traditional knowledge and traditional cultural expressions by third parties or foreign side. More specific legal arrangements regarding traditional knowledge and traditional cultural expressions can give a very positive impact for the State in general and specifically to the local community which is the subject of the owners of traditional knowledge and traditional cultural expressions. Utilization of traditional knowledge and traditional cultural expressions as capital construction of the State because there are plenty of economic potential that will be obtained if the state can provide protection and legal certainty of the traditional knowledge and cultural expressions because of the intellectual property contained therein as a national asset, but it also helps Indonesia to advance national culture in the midst of world civilization and make culture an investment to build the future and national civilization for the realization of national goals as mandated by the 1945 Constitution of the Republic of Indonesia. The implications that will be acceptable by local people as subjects of the rights holders of traditional knowledge and traditional cultural expressions are: 1) the existence of a system that will organize all the data on traditional knowledge and traditional cultural expressions in Indonesia about where traditional knowledge and traditional cultural expressions come from and who are the holders of traditional knowledge and traditional cultural expressions to prevent mutual claims between local communities or from foreign parties; 2) The good recognition both from domestic and abroad of traditional knowledge and traditional cultural expressions possessed; 3 ) Local community rights holders will also receive the economic benefits arising from the utilization of traditional knowledge and traditional cultural expressions; 4) Preventing the occurrence of misappropriation by foreigners; 5) The dispute resolution mechanism pursued by the community holding the rights to traditional knowledge and traditional cultural expressions will be more clear if there is abuse and utilization that harms the rights of the community holders of traditional knowledge and traditional cultural expressions. Therefore, the need for a provision defining who is a community or society as bearers of rights of traditional knowledge is concerned. In this case, traditional societies maintain and develop traditional knowledge and traditional and communal traditional cultural expressions. Delivering this knowledge from generation to generation as the owner of the right to traditional knowledge, or the party that receives the right from the owner of the right to traditional knowledge. 


\section{CONCLUSION}

Based on the description above, it can be concluded: first, broadly speaking, Intellectual Property Rights are rights to wealth that arise or are born due to human intellectual abilities in the form of knowledge, art, literature, technology, where in realizing it requires energy, time, cost and thought. Due to these sacrifices, then a work has value. Traditional knowledge and traditional cultural expressions can be regarded as an object of intellectual property rights as it emerges from practical thinking by teaching and experience passed down from generation to generation. This result of thinking in the form of traditional knowledge is the reason that traditional knowledge and traditional cultural expressions include the work of human intellectuals. Although it can be said to be intellectual, the difference in ownership concepts as outlined in the legal regime of Intellectual Property Rights in Indonesia that promotes originality and is individualistic is very contrary to the concept of ownership of traditional knowledge and traditional cultural expressions and anonymous creators and difficult to determine authenticity because it is inherited from generation to generation.

In addition, the protection of Intellectual Property Rights against traditional knowledge by utilizing the Intellectual Property Rights Law has not fully been able to provide overall protection. This is due to the characteristics of IPR that differ from traditional knowledge. In the protection of IPR in accordance with its exclusive, monopolistic, individualistic nature so that the private domain is very different from the nature of traditional knowledge which promotes collectivism. In addition there are several other aspects that have led to the protection of traditional knowledge and the traditional cultural expressions has not been maximized, namely: 1) Aspects of the substance, is not strictly regulated, both in substance and procedural to obtain legal protection, even if there is still a symbolic nature so as to make the rule ineffective and there is no benefit; 2) Resource aspects of the legal apparatus, there are still very few apparatuses who know the problems of traditional knowledge and traditional cultural expressions, even though in terms of normative rules that are unclear, legal breakthroughs are needed that can be carried out by law enforcement officials; 3) Aspects of legal culture, lack of legal awareness of the community and reluctance of traditional communities to carry out legal processes in the context of violations of intellectual work based on traditional knowledge and traditional cultural expressions. For Indonesia, traditional knowledge is an invaluable national asset, therefore it must be protected and preserved. Legal protection is not only to avoid unfair competition with misappropriation but also beneficial for equity and economic development. By making laws that are sui generis based on traditions that develop in the local community. Protection is intended to improve the welfare of the community, not only for humanitarian purposes as the views of the indigenous people, but directed towards increasing the economic welfare of every member of the community, through access given to foreign companies or other external parties with fair economic benefits and accepted by the community as the owner of traditional knowledge and traditional cultural expressions. 


\section{REFERENCES}

Adriansyah, Yasmi, 2010, Mencari Tempat Terhormat Indonesia, PT. Alumni, Bandung.

Asian - African Forum On Intellectual Property and Traditional Knowledge and Genetic Resources, 18 - 21 Juni 2017 di Bandung.

Badan Penelitian dan Pengembangan HAM Kementerian Hukum dan HAM RI, 2013, Perlindungan Kekayaan Intelektual Atas Pengetahuan Tradisional dan Ekspresi Budaya Tradisional Masyarakat Adat, Penerbit PT. Alumni, Bandung.

Umar, Achmad Zen, "'Pokok-Pokok Kebijakan Pembangunan Sistem HKI Nasional", Jurnal Hukum Bisnis, Vol.13, April 2001,

Friedman. Lawrence M, 1975, The Legal System A Social Science Respective, New York, Russel Sage Foundation.

Marin, Patricia Lucia Cantuaria, 2002, Providing Protection for Plant Genetic Resources Patent, Sui Generis System, and Biopartnerships, Kluwer Law International.

Mencari Format Kebijakan Hukum yang Sesuai Untuk Perlindungan Folklor di Indonesia, http://www.Ikht.net/index.php?option=com_content\&view=article\&id=102:for matperlindungan hukum-folklor\&catid=1:hki-telematika\&ltemid $=37$

Naskah Akademik Pengetahuan Tradisional, 2006, Jakarta, BPHN dan Ditjen HKI RI

Purba, Afrillyanna, et al, 2005, TRIPs-WTO \& Hukum HKI Indonesia: Kajian Perlindungan Hak Cipta Seni Batik Tradisional Indonesia, Jakarta, PT. Rineka Cipta.

Ruswandi, Budi Agus, 2004, Hak Kekayaan Intelektual dan Budaya Hukum, Jakarta, Raja Grafindo Persada.

Salman S, Otje, 2002, Rekonseptualisasi Hukum Adat Kontemporer, Alumni, Bandung.

Sarjono, Agus, 2004, Pengetahuan Tradisional Studi Mengenai Perlindungan Kekayaan Intelektual Atas Obat-Obatan, FHUI, Jakarta.

Spellerber, Ian F, 2007, Biological Diversity, Concerevation and Resource Management, Biodiversity Conservation in Asean Emerging Issues \& Regional Needs, Asean Academic Press, Malaysia.

Sudarmanto, 2005, Produk Kategori Indikasi Geografis Potensi Kekayaan Intelektual Masyarakat Indonesia, Lembaga Pengkajian Hukum Internasional FHUI, Jakarta. 